\title{
Outcomes following minimally invasive imagine-guided percutaneous ablation of adrenal glands
}

\begin{abstract}
Anna Maria Ierardi ${ }^{1}$, Aldo Carnevale ${ }^{2}$, Salvatore Alessio Angileri ${ }^{1}$, Fabio Pellegrino ${ }^{3}$, Matteo Renzulli ${ }^{4}$, Rita Golfieri ${ }^{4}$, Daqi Zhang ${ }^{5}$, Hui Sun $^{5}$, Melchiore Giganti ${ }^{3}$, Gianlorenzo Dionigi ${ }^{6}$, Gianpaolo Carrafiello ${ }^{7}$

${ }^{1}$ Diagnostic and Interventional Radiology Department, ASST Santi Paolo e Carlo, San Paolo Hospital, Via A di Rudinì 8, 20142 Milan, Italy; ${ }^{2}$ Department of Radiology, University Hospital of Ferrara, via A. Moro 8, 44124 Ferrara, Italy; ${ }^{3}$ Department of Morphology, Surgery and Experimental Medicine, Section of Radiology, University of Ferrara, via L. Ariosto 35, 44121 Ferrara, Italy; ${ }^{4}$ Radiology Unit, Department of Experimental, Diagnostic and Speciality Medicine, Sant'Orsola Hospital, University of Bologna, Bologna, Italy; ${ }^{5}$ Division of thyroid Surgery, ChinaJapan Union Hospital of Jilin University, Jilin Provincial Key Laboratory of Surgical Translational Medicine, Jilin Provincial Precision Medicine Laboratory of Molecular Biology and Translational Medicine on Differentiated Thyroid Carcinoma, 126 Xiantai Blvd, Changchun, China; ${ }^{6}$ Division for Endocrine and Minimally Invasive Surgery, Department of Human Pathology in Adulthood and Childhood "G. Barresi”, University Hospital G. Martino, University of Messina, Messina, Italy; ${ }^{7}$ Unità Operativa di Radiologia, Fondazione I.R.C.C.S. Cà Granda Ospedale Maggiore Policlinico, Milan, Italy

Contributions: (I) Conception and design: AM Ierardi, A Carnevale, G Dionigi; (II) Administrative support: SA Angileri, F Pellegrino; (III) Provision of study materials or patients: A Carnevale, AM Ierardi, M Renzulli; (IV) Collection and assembly of data: AM Ierardi, A Carnevale, R Golfieri; (V) Data analysis and interpretation: D Zhang, H Sun; (VI) Manuscript writing: All authors; (VII) Final approval of manuscript: All authors.

Correspondence to: Anna Maria Ierardi. Diagnostic and Interventional Radiology Department, ASST Santi Paolo e Carlo, San Paolo Hospital, Via A di Rudinì 8, 20142 Milan, Italy. Email: amierardi@yahoo.it.
\end{abstract}

\begin{abstract}
Whilst surgery represents the gold standard for the treatment of adrenal primary malignant tumors, metastatic involvement of the adrenal glands is generally approached conservatively; however, surgery for local control has been controversial, and several reports have described the utility of surgical removal in terms of prolonged survival in selected patients. Different techniques, including radiofrequency ablation (RFA), microwave ablation (MWA), laser induced thermal therapy (LITT), cryoablation (CRA), and chemical ablation, are employed in percutaneous image-guided ablation for primary and metastatic malignancies of the adrenal glands, in case of patients with multiple comorbidities or who refuse surgery. Technical success, clinical success and safety were analysed and discussed in this systematic review. Tumor size was found a significant determinant for local disease control; histology of the primary malignancy and coexistence of tumor elsewhere were correlated with prognosis. These procedures resulted to be feasible and safe, with hypertensive crisis representing the most common complication. Although there is lack of evidence in the literature concerning outcomes compared with surgery, percutaneous ablation may represent a useful therapeutic option for controlling unresectable adrenal metastases, offering patients opportunities for improved survival.
\end{abstract}

Keywords: Ablation techniques; adrenal glands; adrenal gland neoplasms; radiofrequency ablation; microwave ablation; laser-induced interstitial thermotherapy; cryoablation; chemical ablation

Submitted Sep 13, 2019. Accepted for publication Mar 13, 2020.

doi: 10.21037 /gs.2020.03.32

View this article at: http://dx.doi.org/10.21037/gs.2020.03.32

(c) Gland Surgery. All rights reserved. 


\section{Introduction}

Clinically unapparent adrenal neoplasms are frequently encountered in routine practice, found in $2-10 \%$ of the population worldwide (1), and the opportunity to discover adrenal masses is constantly increasing thanks to improved sensitivity of imaging techniques (2). Among adrenal lesions, malignancies are overall rare; however, the adrenal glands are a common site for metastases, particularly from lung cancer, renal cell carcinoma (RCC), colorectal cancer, hepatocellular carcinoma (HCC), and malignant melanoma, with adrenal metastases occurring in $3-27 \%$ of cancer patients as reported by autopsy reviews (3).

Metastatic involvement of the adrenal glands is generally treated conservatively, depending on the primary malignancy, by chemotherapy or radiation therapy; however, surgery for local control has been controversial, and several reports have described the utility of open surgical or laparoscopic resection in terms of prolonged survival in selected patients with isolated metastatic disease to the adrenal glands $(4,5)$. Nonetheless, few patients are usually eligible for surgery because of multiple comorbidities, elder age, difficult approach due to altered anatomical planes and fibrosis for previous surgery, or concomitant extra-adrenal cancer.

In recent years, the drive behind the general trend toward minimally invasive procedures represents the result of a diverse combination of factors, primarily the obvious drawbacks of almost any surgical intervention, the development and refinement of new technologies, the aim to reduce peri-operative complications and post-operative recovery time especially in subjects debilitated or who refuse surgery, and patient awareness of emerging therapeutic approaches. Image-guided ablation techniques, successfully employed in diverse clinical scenarios, have been used also for the treatment of malignant adrenal masses. The purpose of this article was to analyse the current evidence on imageguided ablative procedures for malignant adrenal neoplasms in terms of safety and outcomes.

\section{Materials and methods/search strategy}

An extended systematic search in Medline database (via PubMed), including articles related to human medicine was performed. Keywords were chosen according to Medical Subject Heading (MeSH) terms: "adrenal glands", "adrenal gland neoplasms", "ablation techniques", used in combination with the Boolean operators OR and AND respectively.

The bibliographic search provided a total number of 164 citations; two independent reviewers (A.C. and F.P.) screened the initial search results considering titles and abstracts. Both reviewers had experience in data extraction for retrospective and prospective studies. Articles addressing an issue pertinent to ablation of adrenal gland malignant lesions and reporting outcome data were considered potentially eligible for inclusion. In more detail, inclusion criteria were as follows: Englishwritten, human studies dealing with ablation techniques [namely radiofrequency ablation (RFA), microwave ablation (MWA), laser-induced interstitial thermotherapy (LITT), cryoablation (CRA), chemical ablation] used for adrenal gland primary malignancies or metastases, with consideration of outcomes of the procedures; case series of more than 3 patients. Reviews, case reports and studies which did not perform outcome analysis were excluded. All the articles selected by at least one of the reviewers were retrieved for full text evaluation and were jointly discussed to obtain an agreement in case of uncertainty. Additional searches of their reference lists were performed to identify other potentially eligible articles. Data were consequently extracted using an extraction form designed for the purpose. Finally, 20 articles were considered relevant for the aims of the literature review and were therefore included in this work (Table S1).

When indicated, technical and clinical successes, disease free-survival and overall survival were reported. Moreover, also complications were reported. These outcomes were defined as follows:

\section{Technical success}

The definition of technical success varies among different studies. In most studies, technical success rate, was defined as the completion of adrenal ablation according to the planned treatment protocol (6).

\section{Clinical success}

Complete ablation was generally defined as no evidence of enhancing tissue in the treated adrenal gland at postprocedural imaging or at the first follow-up, and this means successful local control of disease; the visualization of any focal area of enhancement in the ablated lesion should be deemed as residual viable tumor at imaging evaluation performed 1 month after the procedure (7). 
Local disease progression or recurrence was generally identified as the appearance at follow-up imaging (more frequently CT performed after 3 months from the procedure) of new enhancing nodules at the site of a previously treated lesion (7).

\section{Progression-free survival}

Progression-free survival was defined as the length of time after treatment during which a patient survives with no sign of the disease $(3,7)$.

\section{Overall survival}

Overall survival was defined as the length of the time after treatment and the death of the patient from any cause (7).

\section{Safety}

All complications were recorded and classified as minor and major; they were assessed according to CTCAE (8). Major complications were defined as complications that, if left untreated, might threaten the patient's life, lead to substantial morbidity and disability, result in hospital admission or substantially lengthen hospital stay, as described by the International Working Group of Image Guided Tumour Ablation (7). Minor complications included typical post-ablation syndrome symptoms (fever, pain, nausea and vomiting) if present $>4$ days after the ablation procedure.

Complications were further divided into two causal categories: those secondary to device placement (pneumothorax, infection and bleeding) and in cases of thermal ablation, those secondary to thermal injury (damage to adjacent organs) (9). Hypertensive crisis (HC) is related to parenchyma destruction (10). HC has been defined as an increase of systolic blood pressure greater than $180 \mathrm{mmHg}$ or an increase in diastolic pressure greater than $120 \mathrm{mmHg}(10)$.

\section{Results}

\section{Radiofrequency ablation (RFA)}

Technical success, when reported, is high, ranging from $93 \%$ to $100 \%$.

In two cases $(11,12)$ the procedure was terminated before complete ablation because the patients developed
HC during the manoeuvre, requiring adequate medical treatment; in one case (12) the ablation was suspended due to frequent ventricular fibrillation and consequent transient myocardial ischemia.

The response rate in terms of complete/partial ablation after the first session varies among the collected series, ranging from $77.3 \%$ to $100 \%$; most residual tumors underwent repeated ablation sessions $(2,3,6,12,13)$. Among different series collected, recurrence rate reported was up to $25 \%(3)$.

Major complications occurred in 0 to $12 \%$ of patients in different studies with inhomogeneous cohorts; these encompasses HC with myocardial ischemia $(3,13,14)$, post-ablation syndrome, deep vein thrombosis leading to subsequent haemorrhage and splenectomy (15), acute renal failure, haemorrhage, heart failure, stroke (2), haemobilia and acute cholecystitis (3), massive pneumothorax (14), and arrhythmia (12). HC has a frequency up to $57 \%$ (3).

Overall survival rate at 3 -year, when reported, ranges between $34 \%$ and $53 \%$, with a mean follow-up of 26.3 to 37 months.

\section{Microwave ablation (MWA)}

Technical success is not reported.

MWA exerts a high local control rate with complete ablation after the first treatment session which varies between the collected series from $80 \%$ to $100 \%$; partially ablated nodules were successfully retreated to total response with further ablative sessions in all cases $(3,15-19)$.

Local recurrence rates are below $25 \%(3,16,20)$.

Botsa et al. (16) have found rates of local recurrence at 3 -month and 1-year follow-up of $19.4 \%$. In their study, lesions treated successfully with a single ablation were smaller than $3 \mathrm{~cm}$ in size, while patients who needed an additional session had a tumor diameter larger than $3 \mathrm{~cm}$ (16). Similar results have been found by Men and colleagues (20), reporting local recurrence rate for smaller tumors (i.e., with diameter $\leq 3.5 \mathrm{~cm}$ ) significantly lower than that for greater lesions.

No major complications were reported by two out of three series describing MWA for adrenal tumors $(17,19)$. $\mathrm{HC}$ was registered with a rate of $5.6 \%(2 / 31)(20)$. Other frequent reported minor complications are pain, postablation syndrome, and mild hypertension $(17,19)$.

Survival data are limited; studies dealing with the treatment of adrenal gland metastases from lung cancer report median overall survival time of 14.6 months and 
12 months $(16,20)$. During the follow-up, patients died due to the general progression of the tumor.

\section{Laser-induced interstitial thermotherapy (LITT)}

Technical success is not reported.

Vogl et al. (21) have reported the use of CT-guided and MR-thermometry-controlled LITT in a small series of 9 patients presenting single adrenal gland nodules. Complete ablation was achieved in a single session for each tumor, producing a volume of necrosis with a mean diameter of $4.5 \mathrm{~cm}$. After a mean follow-up of 10 months, 2 (22\%) tumors demonstrated recurrence at the treated site; two patients died during the follow-up duration for systemic tumor progression.

There were no procedure-related complications.

\section{Cryoablation (CRA)}

Technical success is not reported.

The response rate in terms of complete/partial ablation after the first ablation is high $(90.3 \%$ to $92 \%)$; moreover, patients with residual disease were all successfully retreated in subsequent CRA sessions.

No major complications were reported in the 2 series analysed $(22,23)$. Welch et al. (24) reported HC in $46 \%$ of the cases. Other minor complications included pleural effusion and back pain.

Overall survival rate is reported only by Welch et al. (24). One-, 3-, and 5-year survival rates were $83.9 \%, 45.0 \%$, and $30.0 \%$ respectively; the presence of concomitant extraadrenal disease was a poor prognostic factor, whereas they could not find any association between primary tumor histology and survival.

\section{Chemical ablation}

Technical success is not reported.

Xiao et al. (25) treated 20 metastases in 14 patients. Percutaneous ablation was repeated an average of three times for small lesions and five for larger ones. The complete response rate was $30 \%$ at 24 -month follow-up, whereas a partial response to treatment was verified in the remaining $70 \%$ of cases.

In the treatment of malignant lesions, Shibata and colleagues (26) ablated 9 metastases from HCC in 7 patients with two to four sessions per lesion. Post-procedural CT showed residual enhancing tissue in two lesions (22\%), which were bilateral metastases in the same patient. During the follow-up (6-36 months), 3 nodules (33\%) were further increased in size, while the remaining were not; after 628 months, one patient died from liver failure, and two from extra-adrenal metastatic spread.

No major complications were registered in the 2 reported studies. Fever and pain were the most common adverse events, and one patient experienced adrenal insufficiency $(25,26)$.

About $35.7 \%$ of patients died at 2 years due to extraadrenal disease progression in the series reported by Xiao et al. (25).

\section{Discussion}

Surgical resection, whenever possible, represents the gold standard for primary adrenal neoplasm treatment; conversely, surgery for local control in patients with adrenal metastases is still controversial in the literature. In patients who are poor surgical candidates or who refuse surgery, percutaneous image-guided ablation may be considered a valid alternative.

The best treatment strategy must be decided by a multidisciplinary team including the interventional radiologist, oncologist, surgeon, and endocrinologist $(27,28)$, considering risks and benefits for patients with several comorbidities.

Besides the concerns of patient selection, tumor size represents a relevant factor to be considered while attempting to achieve complete tumor ablation: it seems clear that the smaller is the maximum diameter, the greater the likelihood of a successful complete ablation. Although a consensus has not been achieved yet on a threshold size, better results have been reported for adrenal masses smaller than $5 \mathrm{~cm}(3,29,30)$. Other investigators reported a lower threshold, i.e., 4 (22) or even $3 \mathrm{~cm}$ for lesions successfully treated with a single ablative session $(11,16)$, or to prevent local tumor progression (2).

General contraindications to adrenal ablative therapy are similar to the contraindications of the same procedures applied to other organs. For instance, as with any imageguided procedure, the risk of haemorrhage must be taken into account; therefore coagulopathies should be corrected before the ablation, and the international normalized ratio (INR) should be less than 1.5 and platelet count greater than $50,000 / \mu \mathrm{L}(27)$.

In addition to careful access planning based on imaging assessment, some investigators have reported 
that preprocedural or periprocedural adrenergic blockade may need to be implemented with the aim to prevent $\mathrm{HC}$ $(13,15)$ in cases of nonfunctional tumors due to the sudden release into the systemic circulation of catecholamines normally stored in the adrenal medulla surrounding the tumor (23), and in cases of functional tumors this indication reflects guidelines on pheochromocytomas in the surgical literature (31). Fintelmann and colleagues (23) reported in their series a lower likelihood of HC in tumors greater than $4.5 \mathrm{~cm}$ with no visible viable gland; hence, preprocedural imaging may be also useful to estimate the risk of the most serious and relatively common side effect of otherwise welltolerated procedures.

On the other hand, some reports have suggested that $\alpha$-blockade may not be routinely needed, as most of the HCs encountered were well-controlled after adequate medical treatment (11).

RFA is the most used ablative technique described in literature for the percutaneous treatment of adrenal lesions. Most articles collected for the literature review deal with RFA of adrenal metastases from RCC, lung carcinoma, HCC, melanoma, gastrointestinal tumors and other malignancies; however, RFA has been used to treat not only metastatic tumors but also primary and metastatic adrenocortical carcinomas (ACC) (30).

Mayo-Smith et al. (29) have described the use of RFA in adrenal gland metastasis treatment. They found that the average size of the two adrenal masses that demonstrated viable residual tumor after ablation was $6.0 \mathrm{~cm}$, compared with $3.6 \mathrm{~cm}$ for completely ablated lesions, but this difference was not significant.

In fact, the size of the lesion to be treated is a significant predictor of residual disease after ablation. Recently, Zhou et al. (14) found that patients with residual tumor had significantly larger nodules, and identified the threshold of $3 \mathrm{~cm}$ to predict the likelihood of incomplete ablation. This finding may be explained by the local effect of RFA in tumor thermal damage, since only lesions limited in size [i.e., with a diameter smaller than $4 \mathrm{~cm}$ (6)] can be ablated with each application depending on the electrode type.

Accordingly, Hasegawa et al. (2) confirmed the threshold of $3 \mathrm{~cm}$ to be a significant factor affecting local tumor progression.

Comparing transarterial embolization (TACE) alone with a combination treatment of TACE with simultaneous RFA, Yuan et al. (32) concluded that the second strategy led to a better local control of adrenal metastases from HCC (75.0\% of patients) compared with TACE alone (35.3\%) at the last follow-up assessment.

Really few data are available about the role of CRA; the results described outlined similar effectiveness to other thermal techniques employed for the same purpose, and local control rate $(80.6 \%)$ was comparable to that of surgery (77-83\%) (23).

Chemical ablation was considered a poor alternative in bilateral and large metastases ( $>5 \mathrm{~cm}$ in diameter), in which thermal ablation techniques may produce better results in terms of disease local control (32).

Few studies have analysed the benefits in terms of survival of adrenal ablation, because of small and inhomogeneous patient cohorts, different techniques applied, and shortterm follow-up; moreover, it should be borne in mind that the eventual prognosis of patients strongly depends on the primary malignancy. This makes it difficult to compare the results from different series featuring adrenal ablation.

Frenk et al. (3), describing use of RFA, CRA and MWA to treat 46 adrenal metastases, indicated a median overall survival of 30 months, which was significantly worse in patients with non-small cells lung cancer (NSCLC), which was found a significant predictor of worse outcome. In the whole population, local control and overall survival at 2 years compared favourably with results of surgical removal based on a systematic review of the literature (33).

Age of 65 years or older and the presence of extraadrenal tumors were also identified to be worse prognostic factors (2) in patients with adrenal metastases. Whether the first prognostic determinant is obvious, the latter may be explicated thanks to the higher disease stage even after RF ablation in subjects presenting concomitant extra-adrenal disease.

Another retrospective study (16) included 71 patients with single adrenal metastases from NSCLC, treated by RFA ( $n=35)$ or MWA $(n=36)$; the investigators revealed a median overall survival time of 14.0 months, with no significant difference in survival between the two different technique groups.

The aforementioned work by Yuan and colleagues (32) suggested that a combined therapy for adrenal metastases from HCC may be more effective than TACE alone: the overall survival rate was significantly higher in the group of patients receiving TACE+RFA therapy than in the TACE alone group (at 3 years $55.3 \%$ vs. $44.0 \%$ ), in spite of more complications related to RFA usage that were shown to easily resolve after active management.

Percutaneous image-guided techniques are safe and welltolerated procedure; $\mathrm{HC}$ is the most frequent complication 
reported. However, most cases were successfully treated by prompt medical intervention, and ablations were successfully completed (6). The risk of sudden blood pressure increase is greater during treatment of tumors adjacent to viable adrenal parenchyma than during ablation of larger tumors localized in a gland completely occupied by the lesion (23).

There is disagreement about the role of MWA in inducing HC: some authors have suggested that the rapid rise in temperature may produce such complication more frequently than RFA, due to an excessive release of catecholamines; conversely, other investigators have reported that the risk with MWA could be lower, due to the shorter application time $(18,19,24)$.

Welch et al. (24) and Zhang et al. (34) performed a hemodynamic change analysis during percutaneous adrenal CRA, and concluded that these patients should be pharmacologically pre-treated in a way similar to patients undergoing surgery for pheochromocytoma.

Others minor complications more frequently encountered included pain, post-RFA syndrome, minimal pneumothorax, transient urinary retention or bleeding, reduced renal function, retroperitoneal abscess, small haematoma, and transient arrhythmia, as shown in Table S1.

\section{Conclusions}

Percutaneous image-guided ablation for primary and metastatic malignancies of the adrenal glands is feasible and safe, with zero mortality and negligible morbidity. Currently, there are no large randomized controlled trials which demonstrate the efficacy of this treatment strategy in terms of local progression and survival, compared with surgical removal. However, percutaneous ablation is a useful therapeutic option for controlling unresectable adrenal metastases, offering patients opportunities for improved survival.

\section{Acknowledgments}

Funding: None.

\section{Footnote}

Provenance and Peer Review: This article was commissioned by the Guest Editor (Özer Makay) for the series "Robotic
Adrenalectomy" published in Gland Surgery. The article was sent for external peer review organized by the Guest Editor and the editorial office.

Conflicts of Interest: All authors have completed the ICMJE uniform disclosure form (available at http:// dx.doi.org/10.21037/gs.2020.03.32). The series "Robotic Adrenalectomy" was commissioned by the editorial office without any funding or sponsorship. SAA serves as an unpaid editorial board member of Gland Surgery from June 2019 to May 2021. The other authors have no conflicts of interest to declare.

Ethical Statement: The authors are accountable for all aspects of the work in ensuring that questions related to the accuracy or integrity of any part of the work are appropriately investigated and resolved.

Open Access Statement: This is an Open Access article distributed in accordance with the Creative Commons Attribution-NonCommercial-NoDerivs 4.0 International License (CC BY-NC-ND 4.0), which permits the noncommercial replication and distribution of the article with the strict proviso that no changes or edits are made and the original work is properly cited (including links to both the formal publication through the relevant DOI and the license). See: https://creativecommons.org/licenses/by-nc-nd/4.0/.

\section{References}

1. Crona J, Beuschlein F, Pacak K, et al. Advances in adrenal tumors 2018. Endocr Relat Cancer 2018;25:R405-20.

2. Hasegawa T, Yamakado K, Nakatsuka A, et al. Unresectable Adrenal Metastases: Clinical Outcomes of Radiofrequency Ablation. Radiology 2015;277:584-93.

3. Frenk NE, Daye D, Tuncali K, et al. Local Control and Survival after Image-Guided Percutaneous Ablation of Adrenal Metastases. J Vasc Interv Radiol 2018;29:276-84.

4. Puccini M, Panicucci E, Candalise V, et al. The role of laparoscopic resection of metastases to adrenal glands. Gland Surg 2017;6:350-4.

5. Paul CA, Virgo KS, Wade TP, et al. Adrenalectomy for isolated adrenal metastases from non-adrenal cancer. Int J Oncol 2000;17:181-7.

6. Carrafiello G, Laganà D, Recaldini C, et al. Imagingguided percutaneous radiofrequency ablation of adrenal 
metastases: Preliminary results at a single institution with a single device. Cardiovasc Intervent Radiol 2008;31:762-7.

7. Ahmed M, Solbiati L, Brace CL, et al. Image-guided Tumor Ablation: Standardization of Terminology and Reporting Criteria-A 10-Year Update. Radiology 2014;273:241-60.

8. The National Cancer Institute. Common Terminology Criteria for Adverse Events (CTCAE) v4.0. 2010.

9. Rhim H, Dodd GD, Chintapalli KN, et al. Radiofrequency Thermal Ablation of Abdominal Tumors: Lessons Learned from Complications. Radiographics 2004;24:41-52.

10. Chobanian AV, Bakris GL, Black HR, et al. Seventh Report of the Joint National Committee on Prevention, Detection, Evaluation, and Treatment of High Blood Pressure. Hypertension 2003;42:1206-52.

11. Zhou K, Pan J, Yang N, et al. Effectiveness and safety of CT-guided percutaneous radiofrequency ablation of adrenal metastases. Br J Radiol 2018;91:20170607.

12. Huang J, Xie X, Lin J, et al. Percutaneous radiofrequency ablation of adrenal metastases from hepatocellular carcinoma: a single-center experience. Cancer Imaging 2019;19:44.

13. Wolf FJ, Dupuy DE, Machan JT, et al. Adrenal neoplasms: Effectiveness and safety of CT-guided ablation of 23 tumors in 22 patients. Eur J Radiol 2012;81:1717-23.

14. Zhou W, Herwald SE, Uppot RN, et al. Image-Guided Thermal Ablation for Non-resectable Recurrence of Renal Cell Cancer Following Nephrectomy: Clinical Experience with Eleven Patients. Cardiovasc Intervent Radiol 2018;41:1743-50.

15. Welch BT, Callstrom MR, Carpenter PC, et al. A SingleInstitution Experience in Image-Guided Thermal Ablation of Adrenal Gland Metastases. J Vasc Interv Radiol 2014;25:593-8.

16. Botsa EI, Thanou IL, Papatheodoropoulou AT, et al. Thermal ablation in the management of adrenal metastasis originating from non-small cell lung cancer: A 5-year single-center experience. Chin Med J 2017;130:2027-32.

17. Wang Y, Liang P, Yu X, et al. Ultrasound-guided percutaneous microwave ablation of adrenal metastasis: Preliminary results. Int J Hyperthermia 2009;25:455-61.

18. Venkatesan AM, Locklin J, Dupuy DE, et al. Percutaneous Ablation of Adrenal Tumors. Tech Vasc Interv Radiol 2010;13:89-99.

19. Li X, Fan W, Zhang L, et al. CT-guided percutaneous microwave ablation of adrenal malignant carcinoma:
Preliminary results. Cancer 2011;117:5182-8.

20. Men M, Ye X, Fan W, et al. Short-term outcomes and safety of computed tomography-guided percutaneous microwave ablation of solitary adrenal metastasis from lung cancer: A multi-center retrospective study. Korean J Radiol 2016;17:864-73.

21. Vogl TJ, Lehnert T, Eichler K, et al. Adrenal metastases: CT-guided and MR-thermometry-controlled laser-induced interstitial thermotherapy. Eur Radiol 2007;17:2020-7.

22. Mouracade P, Dettloff H, Schneider M, et al. Radiofrequency Ablation of Solitary Adrenal Gland Metastasis From Renal Cell Carcinoma. Urology 2009;74:1341-3.

23. Fintelmann FJ, Tuncali K, Puchner S, et al. Catecholamine Surge during Image-Guided Ablation of Adrenal Gland Metastases: Predictors, Consequences, and Recommendations for Management. J Vasc Interv Radiol 2016;27:395-402.

24. Welch BT, Atwell TD, Nichols DA, et al. Percutaneous image-guided adrenal cryoablation: Procedural considerations and technical success. Radiology 2011;258:301-7.

25. Xiao YY, Tian JL, Li JK, et al. CT-guided percutaneous chemical ablation of adrenal neoplasms. AJR Am J Roentgenol 2008;190:105-10.

26. Shibata T, Maetani Y, Ametani F, et al. Percutaneous ethanol injection for treatment of adrenal metastasis from hepatocellular carcinoma. AJR Am J Roentgenol 2000;174:333-5.

27. Ierardi AM, Petrillo M, Patella F, et al. Interventional radiology of the adrenal glands: Current status. Gland Surg 2018;7:147-65.

28. Yamakado K. Image-Guided Ablation of Adrenal Lesions. Semin Intervent Radiol 2014;31:149-56.

29. Mayo-Smith WW, Dupuy DE. Adrenal Neoplasms: CTguided Radiofrequency Ablation-Preliminary Results. Radiology 2004;231:225-30.

30. Wood BJ, Abraham J, Hvizda JL, et al. Radiofrequency ablation of adrenal tumors and adrenocortical carcinoma metastases. Cancer 2003;97:554-60.

31. Pacak K, Lenders JWM, Eisenhofer G. Pheochromocytoma: Diagnosis, Localization, and Treatment. Oxford, UK: Blackwell Publishing Ltd, 2007.

32. Yuan H, Liu F, Li X, et al. Clinical efficacy of chemoembolization with simultaneous radiofrequency ablation for treatment of adrenal metastases from hepatocellular carcinoma. Cancer Imaging 2018;18:24-8.

33. Gunjur A, Duong C, Ball D, et al. Surgical and ablative 
therapies for the management of adrenal 'oligometastases' - A systematic review. Cancer Treat Rev 2014;40:838-46.

34. Zhang W, Sun LJ, Xu J, et al. Computed tomography-

Cite this article as: Ierardi AM, Carnevale A, Angileri SA, Pellegrino F, Renzulli M, Golfieri R, Zhang D, Sun H, Giganti M, Dionigi G, Carrafiello G. Outcomes following minimally invasive imagine-guided percutaneous ablation of adrenal glands. Gland Surg 2020;9(3):859-866. doi: 10.21037/ gs.2020.03.32 guided cryoablation for adrenal metastases: local control and survival. Medicine 2018;97:e13885. 
Table S1 Outcomes of patients who underwent percutaneous ablation for malignant adrenal tumors in the studies collected

\begin{tabular}{|c|c|c|c|c|c|c|c|c|c|c|c|c|}
\hline Author, year & $\begin{array}{l}\text { Tumor } \\
\text { no. }\end{array}$ & $\begin{array}{l}\text { Patient } \\
\text { no. }\end{array}$ & $\begin{array}{l}\text { Ablation } \\
\text { technique }\end{array}$ & $\begin{array}{l}\text { Age } \\
\text { (years) }\end{array}$ & Tumor histology & $\begin{array}{l}\text { Mean tumor } \\
\text { size }(\mathrm{mm})\end{array}$ & $\begin{array}{l}\text { Mean follow- } \\
\text { up (months) }\end{array}$ & $\begin{array}{l}\text { Technical } \\
\text { success }\end{array}$ & $\begin{array}{l}\text { Response rate (complete/ } \\
\text { partial ablation) }\end{array}$ & Recurrence rate & Complications & Survival \\
\hline $\begin{array}{l}\text { Wood } \\
2003(30)\end{array}$ & 15 & 8 & RFA & NA & ACC recurrences or metastases & $43[15-90]$ & $10.3[1-20]$ & NA & Complete ablation & Recurrent disease 20\% (3/15) & $\begin{array}{l}\text { No periprocedural complications, } 1 \text { delayed } \\
\text { multimicrobial abscess in a } 90-\mathrm{mm} \text { after his } \\
\text { third RFA }\end{array}$ & NA \\
\hline $\begin{array}{l}\text { Carrafiello } \\
2008(6)\end{array}$ & 6 & 6 & RFA & $\begin{array}{l}67.2 \\
{[55-74]}\end{array}$ & $\begin{array}{l}\text { Metastases from RCC }(n=3) \text {, breast } \\
(n=1) \text {, lung }(n=1) \text {, ovarian cancer }(n=1)\end{array}$ & $29[15-40]$ & $21[6-36]$ & $100 \%$ & $\begin{array}{l}\text { Partial ablation } 16.7 \% \\
\text { (1/6); complete ablation } \\
\text { of the lesion after second } \\
\text { RFA session (10 days) }\end{array}$ & No recurrence & $\begin{array}{l}\text { No major complications; severe hypertension } \\
(n=1) \text {; post-RFA syndrome }(n=1)\end{array}$ & NA \\
\hline \multirow[t]{2}{*}{$\begin{array}{l}\text { Wolf } \\
2012(13)\end{array}$} & \multirow[t]{2}{*}{20} & \multirow[t]{2}{*}{19} & RFA [16] & \multirow[t]{2}{*}{61 [40-84] } & $\begin{array}{l}\text { Metastases from RCC }(n=7) \text {, lung } \\
(n=6) \text {, melanoma }(n=2) \text {, endometrial } \\
\text { carcinoma }(n=1)\end{array}$ & \multirow[t]{2}{*}{$42[20-80]$} & $14[1-67]$ & \multirow[t]{2}{*}{$100 \%$} & $\begin{array}{l}\text { Partial ablation } 18.7 \% \\
(3 / 16) ; 2 \text { metastases from } \\
\text { RCC in the same patient, } \\
\text { then retreated; } 18-\mathrm{cm} \\
\text { melanoma metastasis) }\end{array}$ & \multirow[t]{2}{*}{ NA } & \multirow[t]{2}{*}{$\begin{array}{l}1 \text { major complication (HC with myocardial } \\
\text { ischemia); hypertensive crisis }(n=1) \text {; hematoma } \\
(n=1)\end{array}$} & \multirow[t]{2}{*}{$\begin{array}{l}\text { Progression of primary disease at } \\
\text { extra-adrenal sites leading to death } \\
(16 / 19 \text { patients; } 84.2 \%), 3 / 19 \text { remain } \\
\text { alive at } 6.3 \text { years, } 4.4 \text { years, and } \\
2.6 \text { years post ablation }\end{array}$} \\
\hline & & & MWA [4] & & $\begin{array}{l}\text { Metastases from lung }(n=2) \text {, small } \\
\text { bowel malignancy }(n=1), H C C \quad(n=1)\end{array}$ & & $14.5[3-28]$ & & Complete ablation & & & \\
\hline $\begin{array}{l}\text { Welch } \\
2014 \text { (15) }\end{array}$ & 37 & 32 & RFA [10] & $66[44-88]$ & $\begin{array}{l}\text { Metastases from RCC }(n=16) \text {; } \\
\text { melanoma }(n=7) \text {; colorectal cancer } \\
(n=4) \text {; other malignancies }\end{array}$ & $18[8-28]$ & 26,6 & NA & $\begin{array}{l}\text { Partial ablation } 2.8 \% \\
(1 / 36)\end{array}$ & $\begin{array}{l}\text { Local recurrence } 8.8 \%(3 / 34) \text { : } \\
\text { post CRA } n=2 \text {, post RFA } n=1\end{array}$ & $\begin{array}{l}8,6 \% \text { rate of major complications: post- } \\
\text { ablation syndrome }(n=2) \text {; deep vein thrombosis } \\
\text { and splenectomy }(n=1)\end{array}$ & $\begin{array}{l}\text { Overall survival at } 36 \text { months } 52 \% \text {, } \\
\text { with a median survival of } \\
34.5 \text { months }\end{array}$ \\
\hline $\begin{array}{l}\text { Hasegawa } \\
2015 \text { (2) }\end{array}$ & 41 & 35 & $\begin{array}{l}\text { RFA, RFA } \\
+ \text { AE in } \\
12 \text { patient } \\
{[34 \%]}\end{array}$ & $64.7 \pm 9.6$ & $\begin{array}{l}\text { Metastases from: NSCLC }(n=15), \text { RCC } \\
(n=9) \text {, colorectal cancer }(n=5), \text { HCC } \\
(n=4) \text {, and breast cancer }(n=1) \text {, thymic } \\
\text { cancer }(n=1)\end{array}$ & 33 [12-82] & $\begin{array}{l}30.1[1.2- \\
96.8]\end{array}$ & $100 \%$ & $\begin{array}{l}\text { Partial ablation } 17 \% \\
\text { (6/35); after retreatment } \\
6 \% \text { (2/35) }\end{array}$ & $\begin{array}{l}\text { Local tumor progression } \\
8 / 35 \text { patients }(23 \%) ; \text { primary } \\
\text { local tumor progression rates } \\
29.5 \% \text { at } 1 \text { year and } 43.6 \% \text { at } 3 \\
\text { and } 5 \text { years }\end{array}$ & $\begin{array}{l}8.3 \%(4 / 48) \text { of major complication: acute renal } \\
\text { failure, hemorrhage, heart failure and stroke } \\
44 \% \text { (21/48) of minor complications }\end{array}$ & $\begin{array}{l}\text { 1-, 3-, and } 5 \text {-year overall survival } \\
\text { rates } 75 \%, 34 \% \text {, and } 30 \%, \\
\text { respectively, with a median survival } \\
\text { time of } 26.0 \text { months }\end{array}$ \\
\hline \multirow{2}{*}{$\begin{array}{l}\text { Botsa } \\
2017(16)\end{array}$} & \multirow[t]{2}{*}{71} & \multirow[t]{2}{*}{71} & RFA [35] & \multirow[t]{2}{*}{70 [46-82] } & \multirow[t]{2}{*}{ Metastases from NSCLC } & 33 [15-52] & \multirow[t]{2}{*}{18} & \multirow[t]{2}{*}{$100 \%$} & \multirow[t]{2}{*}{ Complete ablation } & Local recurrence $22.8 \%(8 / 35)$ & \multirow{2}{*}{$\begin{array}{l}\text { No major complication; self-limited, post- } \\
\text { ablation syndrome in } 16 / 99(16.1 \%) \text { of ablation } \\
\text { sessions }\end{array}$} & \multirow{2}{*}{$\begin{array}{l}\text { Median overall survival } 14.0 \text { months } \\
(3-18 \text { months) }\end{array}$} \\
\hline & & & MWA [36] & & & $35[18-60]$ & & & & Local recurrence $19.4 \%(7 / 36)$ & & \\
\hline $\begin{array}{l}\text { Frenk } \\
2018(3)\end{array}$ & 46 & 38 & $\begin{array}{l}\text { CRA [n=30], } \\
\text { RFA [n=12], } \\
\text { MWA [n=9] }\end{array}$ & 66 [41-80] & $\begin{array}{l}\text { Metastases from RCC }(n=17 ; 45 \%) \text {, } \\
\text { NSCLC }(n=10 ; 26 \%) \text {, and other } \\
\text { primary malignancies ( }(n=11 ; 29 \%)\end{array}$ & 28 [7-49] & $37[2-128]$ & NA & $\begin{array}{l}\text { Partial ablation } 11 \% \\
(5 / 46) ; 3 / 5 \text { successfully } \\
\text { retreated with complete } \\
\text { tumor ablation in } 96 \% \\
(44 / 46)\end{array}$ & $\begin{array}{l}\text { Local progression rate } 25 \% \\
(11 / 44) \text {, successfully treated or } \\
\text { retreated; local progression-free } \\
\text { survival at } 1,2,3 \text {, and } 5 \text { years } \\
\text { was } 82 \%, 75 \%, 69 \% \text { and } 55 \%\end{array}$ & $\begin{array}{l}12 \% \text { of major complication (haemobilia } \\
\text { and acute cholecystitis, } n=1 \text {; hypertensive } \\
\text { crisis with cardiac abnormalities, } n=4 \text {; } \\
\text { pneumothorax, } n=1 \text { ); } 6 \% \text { of minor } \\
\text { complications (intermittent urinary retention, } \\
n=1 \text {; self-limited hematoma, } n=1 \text {; hematuria } \\
\text { during ablation, } n=1 \text { ) }\end{array}$ & $\begin{array}{l}1,3, \text { and } 5 \text { years overall survival } \\
82 \%, 44 \% \text {, and } 34 \% \text { respectively }\end{array}$ \\
\hline $\begin{array}{l}\text { Zhou } \\
2018(11)\end{array}$ & 38 & 33 & RFA & 60 [43-75] & $\begin{array}{l}\text { Metastases from lung cancer }(n=16), \\
\text { liver cancer }(n=8), \text { RCC }(n=5) \text {, colon } \\
\text { cancer }(n=3) \text {, and ovarian cancer }(n=1)\end{array}$ & 30 [13-85] & $22.8[3-48]$ & $97 \%$ & $\begin{array}{l}\text { Partial ablation } 18.9 \% \\
(7 / 37)\end{array}$ & $\begin{array}{l}\text { Local recurrence 24.2\% (8/33); } \\
\text { recurrence-free time 27.4 months }\end{array}$ & $\begin{array}{l}4.3 \% \text { of severe complication (HC with acute } \\
\text { myocardial injury } n=1 \text {; massive pneumothorax, } \\
n=1 \text { ); } 48 \% \text { of mild complication (hypertension } \\
\text { crisis, } n=9 \text {; local bleeding, } n=3 \text {; minimal } \\
\text { pneumothorax, } n=2 \text {; reduced adrenal function, } \\
n=2 \text { ) }\end{array}$ & NA \\
\hline $\begin{array}{l}\text { Yuan } \\
2018(33)\end{array}$ & 25 & & TACE $[\mathrm{n}=25]$ & $56.8 \pm 8.8$ & & 35 [12-81] & & & Partial ablation 24\% (6/25) & $\begin{array}{l}\text { Local tumor progression } 7 / 25 \\
\text { patients, } 6.4 \pm 7.3 \text { months }\end{array}$ & $\begin{array}{l}\text { No major complications; pain, post- } \\
\text { embolization syndrome }(\mathrm{n}=13)\end{array}$ & $\begin{array}{l}1,2 \text {, and } 3 \text { years overall survival } \\
88.0 \%, 64.0 \%, 44.0 \% \text { respectively }\end{array}$ \\
\hline $\begin{array}{l}\text { Huang } \\
2019 \text { (12) }\end{array}$ & 22 & 22 & RFA & $53.0 \pm 13.0$ & Metastases from $\mathrm{HCC}$ & $4.0[17-8.0]$ & $10[3-55]$ & $92 \%$ & $\begin{array}{l}\text { Partial ablation } 22.7 \% \\
(5 / 22)\end{array}$ & $\begin{array}{l}\text { Local tumor progression } 22,7 \% \\
(5 / 22 \text { patients); local tumor } \\
\text { progression rate } 3,6, \text { and } 12 \\
\text { months } 15.8,26.3 \text {, and } 26.3 \% \\
\text { respectively }\end{array}$ & $\begin{array}{l}1 \text { major complication (ventricular fibrillation); } \\
\text { hypertensive crisis (3/22, 9\%), arrhythmia (n=1) }\end{array}$ & $\begin{array}{l}6,12,24 \text { months overall survival } \\
79.7,52.6, \text { and } 32.9 \% \text { respectively }\end{array}$ \\
\hline $\begin{array}{l}\text { Welch } \\
2011(24)\end{array}$ & 12 & 12 & CRA & 70 [63-85] & $\begin{array}{l}\text { Metastases from RCC }(\mathrm{n}=6) \text { ), other } \\
\text { malignancies (HCC, melanoma, } \\
\text { squamous cell lung carcinoma, } \\
\text { neuroendocrine large cell carcinoma } \\
\text { of the lung, penile squamous cell } \\
\text { carcinoma, urothelial carcinoma) }\end{array}$ & $2.7[1.2-4.5]$ & $18[3-55]$ & NA & $\begin{array}{l}\text { Partial ablation } 8 \%(1 / 12) ; \\
1 \text { lesion retreated to } \\
\text { complete ablation }\end{array}$ & NA & $\begin{array}{l}\text { No major complications; } 6 / 13(46 \%) \\
\text { hypertensive crisis; } 1 / 13(8 \%) \text { pleural effusion }\end{array}$ & NA \\
\hline $\begin{array}{l}\text { Zhang } \\
2018(34)\end{array}$ & 31 & 31 & CRA & $57.9 \pm 9.6$ & $\begin{array}{l}\text { metastases from lung cancer }(n=18) \text {, } \\
\text { RCC }(n=10) \text {, colon cancer }(n=2), \text { HCC } \\
(n=1)\end{array}$ & $3.0 \pm 0.7$ & $30.5[8-66]$ & NA & $\begin{array}{l}\text { Partial ablation } 9,7 \% \\
(3 / 31) ; 3 \text { patients retreated } \\
\text { with secondary complete } \\
\text { ablation }(100 \%)\end{array}$ & $\begin{array}{l}\text { Local tumor progression } 19,4 \% \\
(6 / 31 \text { patients); } 1-, 3-, \text { and } 5- \\
\text { years local progression free } \\
\text { survival } 80.6 \%, 37.8 \% \text {, and } \\
18.4 \% \text { respectively }\end{array}$ & $\begin{array}{l}\text { No major complications; no hypertensive crisis } \\
\text { (mild blood pressure increase } n=9) \text {, back pain } \\
(n=6)\end{array}$ & $\begin{array}{l}\text { Mean overall survival } 37.1 \pm 4.2 \\
\text { months; } 1-, 3-\text {, and } 5 \text {-year survival } \\
\text { rates } 83.9 \%, 45.0 \% \text {, and } 30.0 \% \\
\text { respectively }\end{array}$ \\
\hline $\begin{array}{l}\text { Wang } \\
2009(17)\end{array}$ & 5 & 5 & MWA & 59 [47-76] & Metastases from HCC $(n=4), \operatorname{RCC}(n=1)$ & $\begin{array}{l}34.8[2.3- \\
4.5]\end{array}$ & 19 [8-31] & NA & $\begin{array}{l}\text { Partial ablation } 20 \%(1 / 5) ; \\
\text { one lesion retreated to } \\
\text { complete ablation }\end{array}$ & No local recurrence & $\begin{array}{l}\text { No major complications; no hypertensive } \\
\text { crisis; pain }(n=4) \text {, mild pleural effusion }(n=1)\end{array}$ & $\begin{array}{l}\text { one patient developed further HCC } \\
\text { foci and bone metastases }\end{array}$ \\
\hline Li 2011 (19) & 10 & 9 & MWA & 54 [41-83] & $\begin{array}{l}1 \text { primary } \mathrm{ACC}, 8 \text { metastases (lung } \\
\text { cancer }=4, \mathrm{HCC}=2 \text {, intrahepatic } \\
\text { cholangiocarcinoma }=1 \text {, } \\
\text { osteosarcoma }=1 \text { ) }\end{array}$ & $3.8[21-61]$ & $11.3[3-37]$ & NA & $\begin{array}{l}\text { Partial ablation } 10 \% \\
\text { (1/10); one lesion retreated } \\
\text { to complete ablation }\end{array}$ & No local recurrence & $\begin{array}{l}\text { No major complications; hypertensive crisis } \\
(n=1) \text {; pain }(n=1)\end{array}$ & $\begin{array}{l}5 / 8 \text { patients with adrenal metastases } \\
\text { died from the progression of primary } \\
\text { tumors or metastases to other } \\
\text { organs }\end{array}$ \\
\hline $\begin{array}{l}\text { Men } \\
2016(20)\end{array}$ & 31 & 31 & MWA & $\begin{array}{l}64.9 \\
{[45-82]}\end{array}$ & metastases from lung cancer & $3.4[1.5-5.4]$ & $11.1[4-32]$ & $100 \%$ & $\begin{array}{l}\text { Partial ablation } 9.7 \% \\
(3 / 31) ; \text { secondary efficacy } \\
\text { rate } 66.7 \%\end{array}$ & $\begin{array}{l}\text { Local tumor progression } 22.6 \% \\
\text { (7/31); median local tumor } \\
\text { progression-free survival } \\
9 \text { months; local tumor } \\
\text { progression-free survival rate } \\
77.4 \%\end{array}$ & $\begin{array}{l}5.6 \%(2 / 31) \text { major complications; pain in } \\
38.9 \%(14 / 36) \text {, mild hypertension, hematoma, } \\
\text { post-ablation syndrome }\end{array}$ & $\begin{array}{l}\text { Median overall survival } 12 \text { months; } \\
\text { 1-year overall survival rate } 44.3 \%\end{array}$ \\
\hline $\begin{array}{l}\text { Shibata } 2000 \\
\text { (26) }\end{array}$ & 9 & 7 & PEI & 64 [58-72] & Metastases from $\mathrm{HCC}$ & $3.8[2.5-6.0]$ & $19.3[6-36]$ & $100 \%$ & Partial ablation $22 \%(2 / 9)$ & $\begin{array}{l}\text { Local tumor progression } 33 \% \\
(3 / 9)\end{array}$ & $\begin{array}{l}2 / 7(29 \%) \text { abdominal pain; } 2 / 7(29 \%) \text { fever; } 1 / 7 \\
\text { (14\%) adrenal insufficiency }\end{array}$ & $\begin{array}{l}3 \text { patients }(42.9 \%) \text { died at } 8-36 \\
\text { months; } 4 \text { patients }(57.1 \%) \text { alive at } \\
6-28 \text { months }\end{array}$ \\
\hline $\begin{array}{l}\text { Xiao } \\
2008(25)\end{array}$ & 20 & 14 & PEI, PAI & NA & $\begin{array}{l}\text { Metastases from lung cancer }(n=9) \\
\text { HCC }(n=6), \text { gastric cancer }(n=3), \text { RCC } \\
(n=2)\end{array}$ & $5.9[3.1-8.6]$ & 25 & NA & NA & $\begin{array}{l}\text { Complete response rate } 30 \% \\
(6 / 20), \text { partial response rate } 70 \% \\
(14 / 20) \text { at } 24 \text { months }\end{array}$ & $\begin{array}{l}\text { No major complications except pain; no } \\
\text { hypertensive crisis }\end{array}$ & $\begin{array}{l}5 / 14 \text { patients ( } 35.7 \%) \text { died at } 2 \text { years } \\
\text { due to extra-adrenal metastases }\end{array}$ \\
\hline $\begin{array}{l}\text { Vogl } \\
2007(21)\end{array}$ & 9 & 9 & LITT & $\begin{array}{l}65 \\
{[58.7-75]}\end{array}$ & $\begin{array}{l}\text { Metastases from colorectal carcinoma } \\
(n=5), \text { HCC }(n=1) \text {, oesophageal } \\
\text { carcinoma }(n=1) \text {, carcinoid }(n=1) \text {, and } \\
\text { RCC }(n=1)\end{array}$ & $4.3[2.0-6.1]$ & $10[1-22.4]$ & $100 \%$ & Partial ablation 22\% (2/9) & $\begin{array}{l}\text { Local tumor progression } 22 \% \\
(2 / 9)\end{array}$ & No complications & $\begin{array}{l}2 \text { patients died due to systemic } \\
\text { tumour progression; longest survival } \\
\text { time } 24 \text { months }\end{array}$ \\
\hline
\end{tabular}

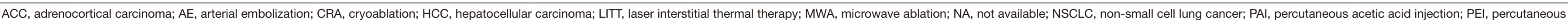
ethanol injection; RCC, renal cell carcinoma; RFA, radiofrequency ablation; TACE, trans-arterial chemoembolization. 